\title{
Rektor A. Egeberg Jensen \\ - en sønderjysk skolemand
}

af KAJ SøREnSEN

A. Egeberg Jensen er i dag mest kendt som forfatter af hjemstavnssangen "For en fremmed barskt og fattigt«. Vigtigere var hans virke som gymnasielærer og rektor og hans indsats i dansk kultur- og ungdomsarbejde fra Genforeningen til pensioneringen i 1958. I tidens stærke nationale spørgsmål stod Egeberg Jensen for en forsonende holdning, og under besættelsen var han klar tilhænger af samarbejdspolitikken. Det gav anerkendelse i Undervisningsministeriet i Kobenhavn, som nærmest tvangsforflyttede den kloge gymnasiemand til den vanskelige post som rektor i Sønderborg. Organist Kaj Sørensen, Taastrup, kaster $i$ artiklen her lys over denne ret ukendte side af nyere sønderjysk skolehistorie.

Andreas Egeberg Jensen blev født den 31. juli 1889 i Gl. Sole i Øster Snede sogn som søn af gårdejer Jens Peter Jensen og Marie Kristine Sørensen. I 1896 begyndte han i Gl. Sole Kommuneskole og fortsatte i 1902 på Vejle Latinskole, hvorfra han blev matematisk student i 1907.

Egeberg ville være lærer i den såkaldte 'højere skole', d.v.s. i gymnasieskolen, og begyndte derfor straks at læse ved Kobenhavns Universitet med historie som hovedfag og dansk og engelsk som bifag. I juni 1912 bestod Egeberg bifagseksamen i dansk og engelsk, og i sommeren 1914 afsluttede han hovedfaget historie. Han havde nu skoleembedseksamen med første karakter og var cand.mag. ${ }^{1}$

I august 1914 blev han ansat som timelærer ved Johannesskolen på Frederiksberg, og sideløbende hermed forberedte han sig til prøven $i$ undervisningsfærdighed (pædagogikum) på Henrik Madsens Skole.

I august 1915 blev Egeberg ansat som adjunkt ved Sorø Akademis skole, og her faldt han godt til. Til stillingen var knyttet hvervet som inspektor for kostskoledrengene, d.v.s. at han skulle føre tilsyn med skolens kostelever (alumnerne) i deres fritid og bo på skolens kostafdeling. 


\section{Genforeningen}

Men så kom Genforeningen i 1920, og den ændrede radikalt tilværelsen for den unge gymnasielærer.

I det sidste krigsår, 1917-18, stod det klart for de fleste, at Tyskland ville gå ud af krigen som taber. Samtidig var der en sikker forvisning om, at der efterfølgende ville blive rejst krav om afståelse til Danmark af $i$ hvert fald en del af de landområder, som vi efter krigen i 1864 måtte give afkald på til Tyskland.

Der er ingen tvivl om, at Egeberg på et tidligt tidspunkt under 1 . verdenskrig fik den tanke at søge til Nordslesvig, såfremt landsdelen på et tidspunkt skulle blive genforenet med Danmark. Hans interesse for den sønderjyske sag kan føres tilbage til 1908, da danskheden $i$ Sønderjylland havde sit strålende landdagsvalg, ikke mindst på Als, og siden da havde han interesseret sig for grænselandets politik. ${ }^{2} \mathrm{Da}$ han ved sit universitetsstudiums afslutning skulle skrive speciale $\mathbf{i}$ hovedfaget historie, valgte han helt naturligt emnet »Danmarks Historie $1848-1866$ «, ${ }^{3}$ den periode, hvor netop det slesvigske spørgsmål så vel indenrigs- som udenrigspolitisk spillede så stor en rolle.

Den 2. marts 1920 blev lærerembederne ved de højere skoler i Sønderjylland opslået, d.v.s. ved de to statsgymnasieskoler i Haderslev og Sønderborg og ved de to statsrealskoler i Aabenraa og Tønder, og allerede den 9. marts sendte Egeberg sin ansøgning om en stilling $i$ Sønderjylland til ministeriet. Det var ham en personlig trang at tilbyde ministeriet sin tjeneste i Sønderjylland, hvis man skulle have brug for ham, skrev han, og han anførte videre, at det ville være ham en glæde at få lov til at være med i arbejdet på at "vinde Sønderjylland helt for Danmark«. Han søgte primært Haderslev Katedralskole, sekundært Sønderborg Statsskole, men da han i Sorø havde diverse biindkomster, søgte han kun forflyttelse, hvis han kunne opnå et lektorat, idet et adjunktur ville betyde en væsentlig indtægtsnedgang for ham. Han ønskede først og fremmest at undervise i dansk i mellemskolen og gymnasiet, $i$ anden række $i$ historie, og det sidste dog kun, hvis han samtidig kunne få dansktimer. ${ }^{4}$ Hensigten var klar: Han vil være med til at gøre det genvundne land dansk og skabe interesse for dansk sprog, litteratur og kultur.

Som nævnt var det ministeriets hensigt at oprette to statsgymnasieskoler, i Haderslev og Sønderborg, og to statsrealskoler, i Aabenraa og Tønder. Efter at stillingerne var blevet opslået, viste det sig imid- 
Andreas Egeberg Jensen som nybagt cand.mag. $i$ 1914. Foto $i$ privateje.

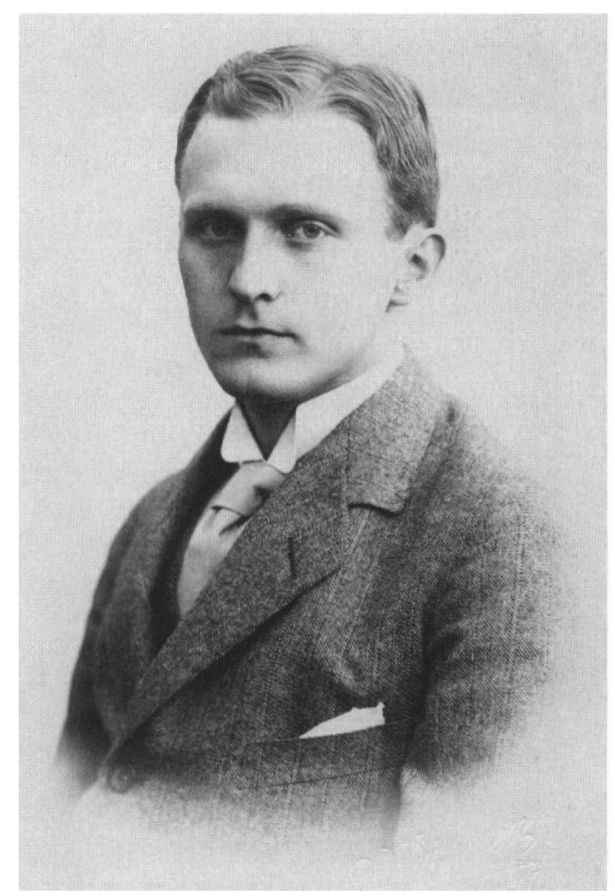

lertid, at der i både Aabenraa og Tønder var et udbredt ønske om også at få gymnasieskoler dér. Undervisningsinspektøren støttede helhjertet ønsket, og undervisningsministeren sørgede for de bevilgende myndigheders tilslutning. ${ }^{5}$

Som rektor for statsskolen i Tønder udnævnte ministeriet den 40årige adjunkt ved Metropolitanskolen i Kobenhavn, Axel J. West. Egeberg og West kendte hinanden fra Sorø Akademi, hvor de havde været kolleger fra 1915 og tre år frem. Vi ved, at West på et tidspunkt $i$ foråret 1920 henvendte sig til Egeberg og tilbød ham et lektorat i Tønder, ${ }^{6}$ men vi ved ikke, hvad Egeberg svarede. Dog fremgår det, at han meldte sig som ansøger til et lektorat $\mathrm{i}$ Tønder, da stillingerne her og i Aabenraa blev opslået 15. maj. Stadig prioriterede han dog ansættelse ved skolerne i Haderslev eller Sønderborg højest. ${ }^{7}$

Egeberg opfattede ikke ansøgningen som et valg for livet. Han rejste ikke til Sønderjylland med en livsstilling for øje. Nej, han ville opleve en grænseflytning $\mathrm{i}$ praksis og i nogle år "være med $\mathrm{i}$ arbejdet på at vinde Sønderjylland helt for Danmark «. Når så tingene var faldet på plads, han regnede selv med en 7-8 år i det sønderjyske, ville 
han tilbage, hvor han kom fra: Til Sorø Akademi. ${ }^{8}$ Det kom imidlertid til at gå ganske anderledes!

\section{Tønder Statsskole}

Åbningen af Tønder Statsskole fandt sted den 25. august 1920, og elevtallet var i begyndelsen kun 126, men voksede $\mathrm{i}$ årets løb til lidt over 200. Det var i høj grad "sammenbragte« børn, lærerne fik at arbejde med: Eleverne kom fra så vel danske som tyske skoler, nogle elever havde gået i fællesskole, andre havde gået i drenge- eller pigeskole. Nogle elever talte dansk, andre havde svært ved at udtrykke sig på og forstå dansk. En del elever var tydeligt præget af krigstidens

\section{Ledige Embeder og Bestillinger.}

Lifter cienforeningen vil der $i$ de under 1. Afstemningszome horrute sonderjydske landsdele blivo opreltet folgende Slatsskolex:

[in liymnasienkole i llaklersles inued 3 l.inier?

lin Gymmasieskole i Sundrolnng (med nysprogling on matematisk-nakmridenskabelig linie:

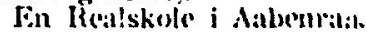

lin Realskole i T'onder.

Vol disse: Skoler vil der vare at an-

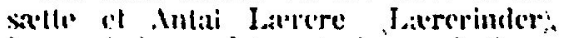
liwrved benterkes, al der vel Gymnasiexkolerne vil kunne ansielles biade Lektorer, Adjunkler ox andre lacrere, se 'Tjenestemindslovens sis 1137-113!, ved Realskolerne Jarrexe at de 2 sidste kialegorier.

Med Stillingerne vil der vire forbundet lonning som for de tilswirente Stillinger ved Stalsskolerne med Tillieg efter Tjenestrmandslovens liegler.

Tjenestealderen for Adjunkier og andie Iarrere vil blive ben'ghet efter $R:$ leme i l'jenestonamelslovens \& 113s, 3 . Stk., og s 11330 . 1. Stk., dogr wilem Tidsbegransningen lil 8 Air.
Dette opslag vedrorende gymnasielærerstillinger $i$ Sonderjylland $i$ Statstidende fra 4. marts 1920 blev indledningen til Egeberg Jensens kommende virke $i$ den genvundne landsdel. 
uro, og der var i det hele taget stor uvidenhed om alt, hvad der angik Danmark og danske forhold.

Egeberg underviste det første år i dansk, engelsk og historie i mellemskolen samt i dansk i Ig. Han havde også onsket at få sang, men det ønske blev ikke opfyldt. 9

I 1935 mindedes han de første år på Tønder Statsskole med bl.a. følgende ord: "Med stor glæde husker jeg mine timer i dansk fra de første år. Aldrig før eller senere har jeg haft så lydhøre tilhørere, når jeg læste op af dansk litteratur, og aldrig har mit eget sind følt glæden og rigdommen ved dansk åndsliv så stærkt som i disse år, og jeg tror, at alle mine fagkolleger havde det på samme måde. Men hvad jeg især mindes, er den forbløffende kærlighed til skolen og trang til samling om denne, som besjælede næsten alle elever ${ }^{10}{ }^{10}$

Der er ingen tvivl om, at det var sådan, Egeberg huskede det, men helt så rosenrød var situationen trods alt ikke. Efter et halvt år på Tønder Statsskole noterede han: "Efterhånden klares det for mig, hvor vanskelighederne ligger. De er i $\mathrm{Ig}$ og $4 \mathrm{~m}$ [ellem] meget store. Mange elever dér er tyskprægede og undertiden også tysksindede, og det er meget sværere, end jeg havde troet, at arbejde med dem «. ${ }^{11}$ Men arbejdet $\mathrm{i}$ dansktimerne bar frugt, og i efteråret 1922 kunne han skrive: "Jeg er ellers meget glad ved mine timer. De elever, der den første vinter var kritiske og overlegne over for alt dansk, er blevet mine gode venner og interesserede elever. Der er ikke én, som jeg ikke er glad for $i$ hele skolens børneflok «. ${ }^{12}$

En af eleverne i Ig, Margrete Schultz, f. Andresen, mindedes 65 år senere de første år i Tønder Statsskole. Om lærerne skriver hun bl.a.: "De var så godt som alle unge, nogle havde søgt embedet af idealistiske grunde, og fordi de følte arbejdet som en stor udfordring, andre havde nok ladet sig lokke af et klækkeligt stedtillæg. Sværest var opgaven i dansk, men lektor Andreas Egeberg Jensen, der havde opgivet en stilling på Sorø Akademi for Tønder Statsskole, var opgaven voksen. Han måtte lade os skrive diktat hele Ig igennem. Han lærte sig at tale sønderjysk. Han var en storartet dansklærer, stærkt engageret i sit fag, meget levende i sin undervisning “. ${ }^{13}$

Hen mod skoleårets slutning skulle lærerne for hver af deres klasser opgive til skolens rektor, hvad de havde arbejdet med $\mathrm{i}$ årets lob. Selv om papir som bekendt er tålmodigt, er disse pensaopgivelser et vigtigt kildemateriale. Hvad angår Egebergs fem ugentlige timer $i$ dansk i Ig, blev der i begyndelsen arbejdet meget med diktater og 
stileøvelser, senere kom hjemmestile til, og ordforklaringer og analyse af danske tekster var en vigtig del af timerne. Klassen læste $i$ årets løb Jeppe på Bjerget (Holberg), Den politiske Kandestøber (Holberg), Aladdin (Oehlenschläger), Aprilsnarrene (Heiberg) og Sparekassen (Hertz), og for klassen oplæste Egeberg Præsten i Vejlby (Blicher), Hosekræmmeren (Blicher), Svend Dyrings Hus (Hertz) og Gildet på Solhaug (Ibsen). Holbergs Erasmus Montanus blev gennemgået i tilknytning til Det Kgl. Teaters forestilling i Tønder. Desuden blev der læst 25 sider efter Bertelsens oldnordiske Læsebog. ${ }^{14}$

Tønder var i 1920 en ret så provinsiel by, der i mange år havde stået i skyggen af Flensborg. Alligevel fandt Egeberg byen henrivende, især den indre by med den fine bygningskultur. Men han, der var vant til at gå i Sorøs alleer og skove, fandt $i$ begyndelsen omegnen trist. Han forstod ikke med det samme fladernes poesi. Hans trøst var Kloster Kirke, og Møgeltønder, der var det smukkeste, han nogensinde havde set, næst efter Oxford! ${ }^{15}$

Hurtigt tog Egeberg fat på et aktivt ungdomsarbejde. Festlighederne $\mathrm{i}$ anledning af skolens åbning var knap overstået, før han og et par andre lærere nogle eftermiddage om ugen samlede interesserede elever til forskellige former for leg og sport. De arrangerede også vandre- og cykelture for eleverne $\mathrm{i}$ fritiden, ${ }^{16}$ og her blev der sunget meget. Egeberg var en poetisk natur, og han skrev bl.a. sangen $\gg \mathrm{Vi}$ drenge fra Tønder«. I foråret 1922 besluttede han, at han ville lave en skolesang, en der kunne synges af alle - også af pigerne - og så skrev han "For en fremmed barskt og fattigt«. Hans kollega Ernst A. Kiørboe satte melodi til teksten, og sangen blev første gang sunget officielt ved skolens translokation i juni 1922. ${ }^{17}$

Ud over den daglige undervisning og deltagelse i diverse fritidsaktiviteter for eleverne påtog Egeberg sig også hvervet som Tønder Statsskoles første bibliotekar. Dette hverv beholdt han i hele 16 år og blev således den, der kom til at lægge grunden til skolens store bogsamling. ${ }^{18}$

\section{Foredrag}

Egeberg havde kun boet $\mathrm{i}$ Tønder i et par måneder, da han gik i gang med at udarbejde et foredrag om de danske fædrelandssange gennem tiderne. I et brev fortæller han selv, at han havde på fornemmelsen, at de danske nordslesvigere sad rundt omkring i landsdelen og ventede 


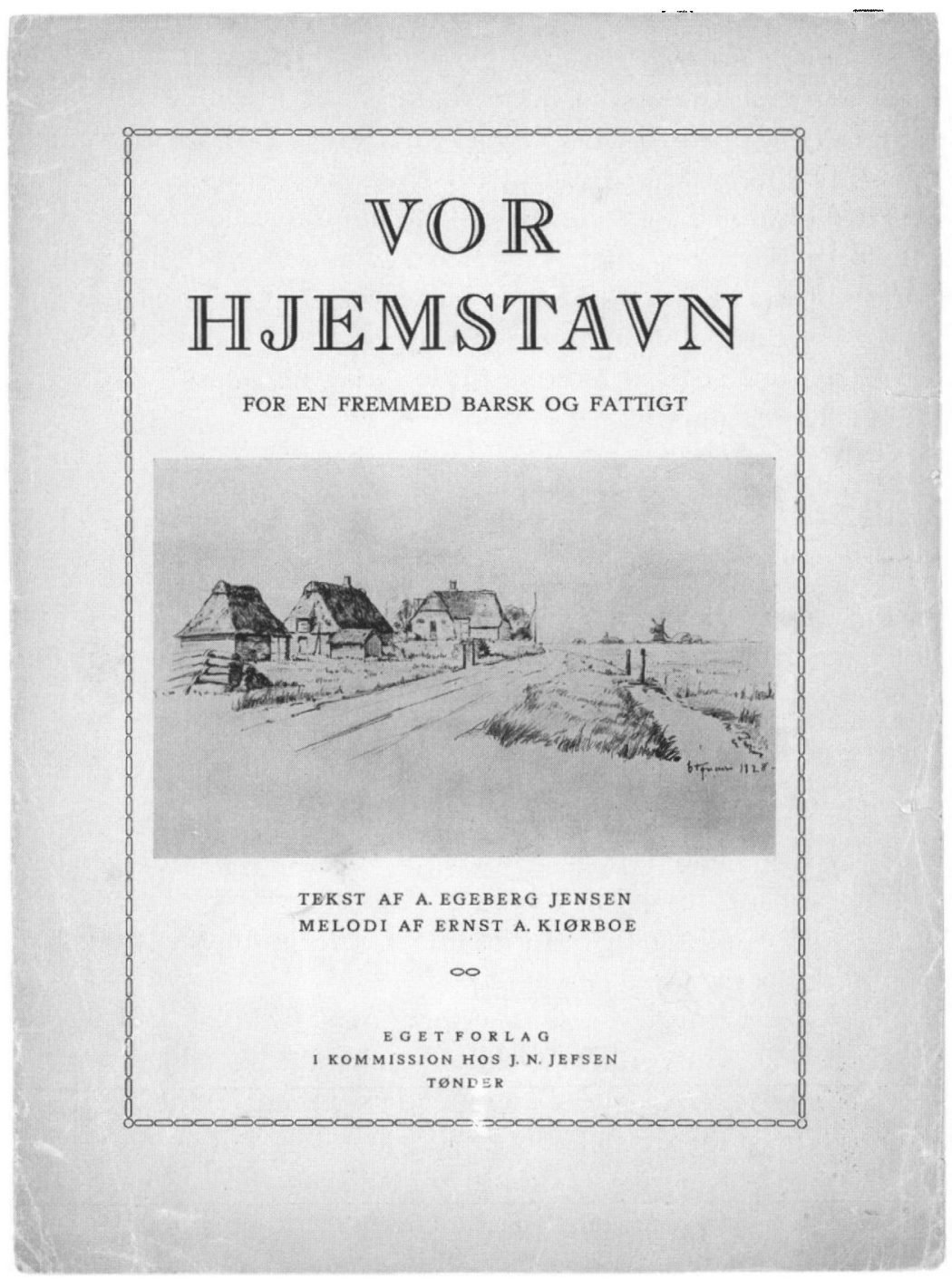

Titelside af tekst-og melodiblad til A. Egeberg Jensens hjemstavnssang, her med titlen "For en fremmed barsk og fattigt" - ikke barskt, som det hedder $i$ Højskolesangbogen. Tryksag $i$ Tonder lokalhistoriske Arkiv.

på, at nogle af »dem nordfra« skulle komme og fortælle. Og da han nu var kommet derned, og da han så gerne ville lære befolkningen at kende, ville han da ikke være en utro tjener, men sætte sin plov $\mathrm{i}$ jorden. ${ }^{19}$ 
Den 12. december 1920 holdt Egeberg så i Jyndevad sit foredrag om de danske fædrelandssange gennem tiderne, og det var, så vidt vi ved, det første af hans ca. 500 foredrag i Nord-og Sydslesvig. Kort tid efter gentog han foredraget $\mathrm{i}$ Jejsing. Efter nytår var der allerede planlagt to foredrag: et $\mathrm{i}$ det nyindviede Tønderhus om de danske folkeviser samt et på Tønder Statsskole om dansk litteratur i det 19. århundrede. Derefter fulgte en foredragsrække om danske digtere, først et portræt af H.C. Andersen og senere et af Steen Steensen Blicher. ${ }^{20} \mathrm{På}$ baggrund af sin omfattende foredragsvirksomhed kom Egeberg på den måde til at bidrage til det, man har kaldt Nordslesvigs åndelige genforening. ${ }^{21}$

\section{Politik}

Fra sit barndomshjem medbragte Egeberg en stor politisk interesse. ${ }^{22}$ Årsagen, til at han aldrig trådte aktivt ind i politik, skal nok findes dels $i$ hans lange sygdomsperioder - han var livet igennem plaget af astma og af en aldrig fuldt helbredt tuberkulose og led ofte af en svælg- og strubelidelse - og dels i hans mange fritidsbeskæftigelser, ikke mindst hans meget omfattende foredragsvirksomhed. Han indrømmede dog altid åbent og ærligt, at han var venstremand, og som sådan var han $\mathrm{i}$ felten. Han deltog som Venstres våbendrager i vælgermøder før folketingsvalgene og byrådsvalgene i 1920'erne og blev i hvert fald en enkelt gang opfordret til at opstille som Venstres kandidat til byrådet, men takkede nej. ${ }^{23}$

Når det gjaldt det store nationale spørgsmål, tyskerne, kom Egeberg godt ud af det med de enkelte tyskere, han kendte, men han var nervøs for Tyskland som en eventuel kommende stormagt. I sine breve skrev han om sin frygt for konstellationen Rusland-Tyskland imod Frankrig, samtidig med at Amerika var koldt, England lunkent og Italien fantastisk, som han udtrykte det, ${ }^{24}$ og han var harmdirrende over og tog skarp afstand fra den politiske indflydelse, som tyskerne via den økonomiske krise prøvede at få i Nordslesvig: "Den økonomiske krise har slået mange førende danskere til jorden, den danske bank i Tønder står, skønt den er rekonstrueret, meget svagt, de to direktører, ${ }^{25}$ ubestridt de to bedste danske mænd i Tønder, har mistet deres indflydelse over befolkningen; Høyer-Trøjborg, en af vore allerbedste mænd på landet, ${ }^{26}$ siges at være helt færdig til foråret, og mange, mange sidder i det på samme måde. Under disse forhold er det nærmest dødbringende, at ty- 
ske pengeinstitutter prioriterer gårdene langt over deres nuværende værdi mod at få forkøbsret til gårdene. Det giver dem naturligvis store økonomiske tab, men da de sikkert finansieres både af den preussiske stat og af private foreninger, betyder det mindre over for den store fordel at få fat i Nordslesvigs jord. Og på dansk side står der en lille flok trofaste + det store gros, der ganske vist to gange om ugen synger, at gamle Danmark skal bestå, men som underforstår, indtil studepriserne i Hamborg når en vis højde. Og vi andre »dem nordfra«, ja, de fleste af os er vist - som jeg selv - lammede i vor foretagsomhed, fordi vi føler os som fremmede hernede, føler, at vore ord har ingen vægt, fordi vi regnes for mindreværdige, og så har vi vel alle fået en lede ved den slesvigske form for patriotisme, højrøstet og fraseflommende i medgangens dage, og skældsordslyrisk i modgangen $"{ }^{27}$

Men forholdene bedredes i slutningen af 1920'erne, og langsomt vendte Egebergs livsmod tilbage. Økonomien var i bedring, om end det gik langsomt, og stemningen var efterhånden rigtig god. Men så kom den store verdenskrise i 1930'ernes begyndelse med mange tvangsauktioner. De overbeviste danske nordslesvigere svingede ikke over til tyskerne af økonomiske grunde, men krisen lagde en stærk dæmper på glæden ved Genforeningen. De truende toner sydfra og nazisternes fremmarch fik atter Egeberg til at vakle, og i perioder var han ramt af alvorlige depressioner. Tysklands indmarch i Østrig og Tjekkoslovakiet, og Ruslands angreb på Finland fik Egeberg til at udbryde: »Gid Fanden vil hente sin gesandt Stalin og tage Adolf med «! $!^{28}$

Ved den tyske besættelse af Danmark den 9. april 1940 var Egeberg indlagt på Kolding Sygehus. Han kunne imidlertid ikke i denne situation ligge uvirksom hen og forlangte at blive udskrevet øjeblikkeligt, så han dagen efter kunne være på Haderslev Katedralskole, som han på det tidspunkt var rektor for.

Besættelsesårene blev frygtelige for Egeberg. En af hans gode venner, Poul Andersen i Højer, besøgte ham to dage efter tyskernes besættelse af Danmark og fortæller følgende: „Sammen med min kone besøgte jeg ham [Egeberg] den 11. april 1940. Jeg var rystet over at se, hvordan begivenhederne havde mærket min ven; det var en syg og træt mand, vi besøgte ${ }^{29}$

Egeberg troede fuldt og fast på forhandlingspolitikken: »Jeg er bange for følelsespolitik. Det er godt, at hovedparten af befolkningen er arbejdere og bønder, de er mindre modtagelige for følelsespsykose«, skrev han. ${ }^{30}$ 
Og da så frihedens time oprandt i 1945, stillede han sig - ikke uventet - på den side, der manede til besindighed og overbærenhed. Han gjorde det, fordi han var overbevist om, at det ville tjene fremtiden bedst. "Jeg har altid syntes, at hævn er en plebejerfølelse«, sagde han. ${ }^{31} \mathrm{Og}$ han kunne se, at en af de gode ting ved besættelsesårene havde været, at de havde drevet det gamle land og Nordslesvig tættere sammen og forenet dem. "Nazismen har gjort os den kæmpetjeneste at få os til at glemme småting, der skiller «, skrev han. ${ }^{32} \mathrm{Og}$ det var han lykkelig for, også selv om han endnu omkring 1950 mente at kunne spore - ikke som en politisk bevægelse, men som en følelse en vis slesvigsk separatisme hos de ældre.

\section{Rektoransøgninger}

Det vides ikke nøjagtigt, hvornår Egeberg besluttede sig til, at han ville være rektor, men tanken om at blive skoleleder er sikkert vokset i takt med, at han blev klar over, at hans helbred i virkeligheden ikke kunne tåle det vestslesvigske klima. Og da hans læge i 1925 i anledning af en stadig tilbagevendende bronchitis anbefalede ham at sege til Østkysten eller til Øerne, ${ }^{33}$ så har han sikkert på det tidspunkt truffet sit valg: Når han nu alligevel skulle væk fra Tønder Statsskole, hvorfor så ikke søge et rektorembede? På en måde ligger tanken jo lige for, på den anden side forstår man ham ikke helt.

På Sorø Akademi havde han - hvor glad han end var for at være der - været ked af den på stedet herskende faste og gamle tradition, som ikke altid stemte overens med hans pædagogiske målsætning, ${ }^{34}$ og selv om han satte pris på Tønder Statsskoles rektor, har den noget håndfaste ledelsesform sikkert været ham imod. Det er $i$ hvert fald klart, at fik han sin egen skole, ville han som rektor have langt større mulighed for at præge den med de pædagogiske tanker, som optog ham, end hvis han blot var lektor. På den anden side: Han nød - som få - samværet med eleverne i klasselokalerne. Og ikke nok med det, han nød samværet med eleverne i fritiden. Hvordan kunne han dog få den tanke at skulle bruge næsten al sin tid på administrative opgaver på et rektorkontor i stedet for ude blandt eleverne? Desuden havde han de første år i Tønder haft så mange, og også enkelte meget lange, fraværsperioder på grund af sygdom, at en ansvarlig undervisningsminister helt bestemt måtte være yderst betænkelig ved at overdrage ham den daglige ledelse af en skole. 
I maj 1925 søgte Egeberg det ledige rektorat ved Horsens Statsskole. Da ansøgningsfristen var udløbet sendte ministeriet som sædvanlig de indkomne ansøgninger til undervisningsinspektøren for gymnasieskolerne med anmodning om en vurdering samt en indstilling til det ledige embede. Sådan var proceduren altid, og i langt de fleste tilfælde udnævnte undervisningsministeren den person, som undervisningsinspektøren pegede på. Undervisningsinspektøren udtalte sig om de enkelte ansøgere på baggrund af oplysninger i undervisningsinspektionen, på baggrund af personligt kendskab til ansøgerne, som altid søgte foretræde for undervisningsinspektøren, i hvert fald før de første gang søgte et rektorat, men også af og til ved senere ansøgninger, eller på baggrund af oplysninger fra den stab af faglige medhjælpere, som var ansat $i$ undervisningsinspektionen, og som tog rundt på skolerne og overværede undervisningen hos de lærere, som underviste i den enkelte medhjælpers egne fag.

Egeberg var givetvis til samtale hos undervisningsinspektøren i anledning af ansøgningen om rektoratet i Horsens. Her havde han dog ikke mange chancer, dels på grund af sine kun 36 år og dels på grund af de mange sygedage. På den anden side skriver undervisningsinspektøren $i$ sin vurdering af Egeberg, at han regner ham for at have adskillige forudsætninger for med tiden at blive en dygtig rektor. Egeberg har da nok fået et lille skulderklap med opfordring til at søge igen om nogle år. ${ }^{35}$

Og det gjorde han! I sommeren 1927 søgte han rektorembedet ved Svendborg Statsskole, og i 1929 rektorembedet ved Kolding højere Almenskole.

I foråret 1930 søgte Egeberg rektorembedet ved sin egen skole. Det var blevet ledigt, da A.J. West efter eget ønske, p.g.a. sygdom i familien, blev forflyttet til Sønderborg Statsskole. ${ }^{36}$ På trods af et massivt ønske fra kolleger og forældre om at få Egeberg til rektor, udnævnte ministeriet dog lektor ved Sønderborg Statsskole Jakob Randrup til ny rektor i Tønder. ${ }^{37}$

I juli 1932 søgte Egeberg stillingen som rektor for Viborg Katedralskole. Af brevvekslingen mellem ministeriet og undervisningsinspektøren fremgår det, at Egeberg nu er med helt fremme i førerfeltet, og valget kommer da også til sidst til at stå imellem Egeberg og en anden, en fem år ældre, ansøger. Det bliver alderen, der gør udslaget. Den ældste udnævnes, så Egeberg må vente endnu en gang. ${ }^{38}$

I maj 1936 søgte Egeberg rektoratet ved sit eget gamle gymnasium, 
Vejle kommunale Gymnasium, men trak en uge efter ansøgningsfristens udløb ansøgningen tilbage. Vi kender ikke årsagen, men ministeriet har muligvis stillet ham rektorembedet ved Haderslev Katedralskole i udsigt. Ministeriet vidste nemlig, at dette embede ville blive ledigt året efter p.g.a. pensionering, og vi ved, at man i ministeriet betragtede Egeberg som selvskreven til denne stilling. ${ }^{39}$

Den 26. maj 1937 blev rektorembedet ved Haderslev Katedralskole opslået. Egeberg søgte stillingen, og det fremgår tydeligt af sagens akter, at der på intet tidspunkt, hverken i undervisningsinspektionen eller i ministeriet, har været nogen som helst tvivl om, at den stilling var Egebergs. Den 5. juli 1937 modtog Egeberg den kongelige udnævnelse til rektor i Haderslev pr. 1 . august 1937 at regne. ${ }^{40}$

\section{Haderslev}

I begyndelsen af august 1937 flyttede Egeberg ind i rektorboligen i Laurids Skausgade 13, og den 16. august begyndte det nye skoleår. Man var i Haderslev vidende om, at Egeberg ved sin faglige dygtighed og sin stilfærdige ro havde skabt sig en smuk position $i$ Tønder, og det havde derfor blandt Katedralskolens lærere været et udtalt ønske at få ham til ny rektor, et ønske som forældrenævnet fuldt ud bakkede op. Der var derfor glæde og store smil overalt, da man mødtes den første skoledag efter ferien, og Egeberg fik fra alle sider en hjertelig velkomst.

Senere har han fortalt, at han fandt Haderslev mere hyggelig og meget mere dansk end Tønder og tonen mere lyrisk. Der var på Katedralskolen færre tyske elever end i Tønder Statsskole, men det skyldtes nok især, at det tyske gymnasium i Aabenraa nu var kommet godt i gang, så en del tyske elever søgte derhen. ${ }^{41}$

I Tønder havde forbindelsen mellem statsskolen og seminariet ikke været speciel god, og Egeberg havde oplevet, hvordan nogle af lærerne på statsskolen så lidt ned på seminariets lærere. I Haderslev lagde han derfor straks fra starten vægt på at få opbygget en god kontakt til seminariets forstander og til dets lærere. Egeberg fandt det vigtigt, at alle skoler $\mathrm{i}$ byen støttede hinanden og arbejdede hånd $\mathrm{i}$ hånd, og han vidste, at der mange steder blev konstrueret modsætninger mellem gymnasium og folkeskole. Derfor henvendte han sig også til byens folkeskoler og fik skabt en fin kontakt til dem. ${ }^{42}$

Det var imidlertid ikke alle modsætningsforhold, der lod sig løse så let. På grund af den stigende trussel fra syd, trådte de politiske 


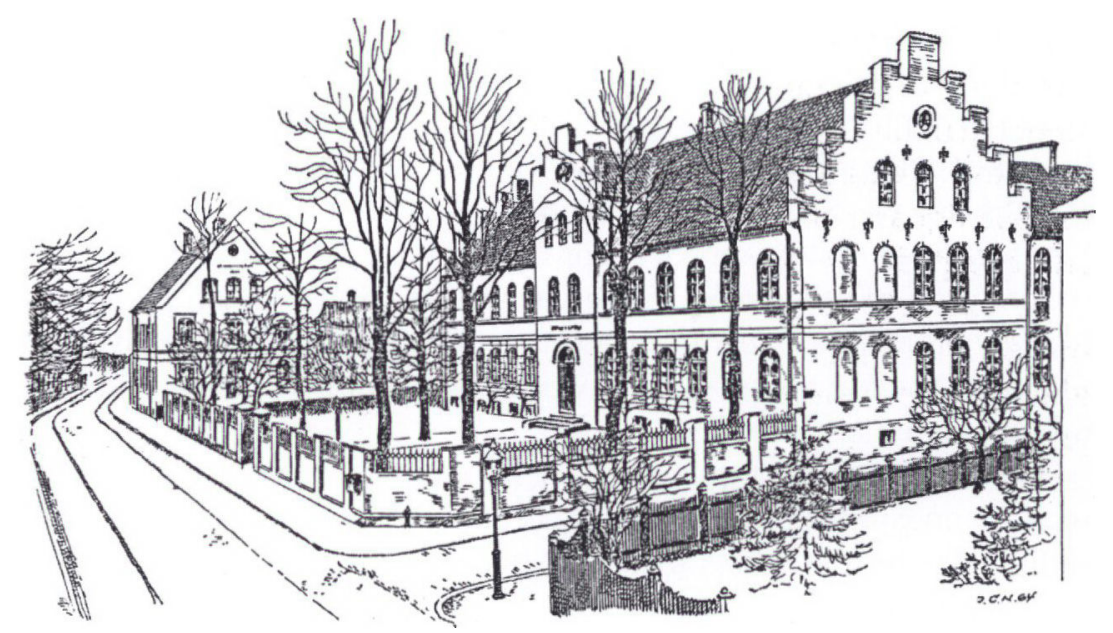

Haderslev Katedralskole, hvor Egeberg Jensen var rektor 1937-1941.

modsætninger efterhånden tydeligere frem og kunne godt, også $\mathrm{i}$ begyndelsen af Egebergs rektortid, påvirke hverdagen på Haderslev Katedralskole. Egeberg forsøgte at mægle og appellerede til menneskelig forståelse, og det lykkedes også at undgå sammenstød inden for skolens mure. Da tingene senere spidsede til, forbød han på det kraftigste skolens lærere og elever at diskutere den politiske situation i timerne. Dagen efter tyskernes besættelse af Danmark sagde Egeberg ved morgensangen bl.a.: "Lad os prøve at holde modet og humøret oppe. Vi har længe levet trygt og godt i Danmark, mens andre led ondt, nu må vi bære vor part af verdens lidelser og byrder. Lad os ikke tabe modet for det. Det er mit indtryk, at de tyske invasionstropper i går optrådte med stor selvbeherskelse og ro og udæskede ikke. Lad os gøre vort til, at denne optræden ikke ændres, så kan den ulykke, som i første øjeblik syntes umulig at bære, dog måske blive tålelig. Afhold jer fra alle demonstrationer og optræd værdigt og tilbageholdende. Og husk så, at selv om natten er aldrig så mørk og lang, så kommer der igen en dag «. ${ }^{43} \mathrm{Vi}$ skal senere se, at det var toner, som vakte anerkendelse i ministeriet.

\section{Forholdet til eleverne}

Egeberg var god til at fange sine tilhøreres opmærksomhed. Han kunne tale, så ikke kun voksne, men også børn og unge mennesker for- 
stod det. Bl.a. med sine skoletaler banede han vejen for det, som han mest af alt ønskede sig: Et godt og tillidsfuldt forhold til eleverne.

Da Egeberg blev udnæunt til rektor, frygtede han, at den tætte forbindelse mellem ham og eleverne ville forsvinde. Han havde svært ved at forestille sig, at eleverne kunne være lige så åbne og naturlige over for deres rektor som over for deres lærer. Men her regnede han forkert! Han måtte ganske vist til en vis grad indstille sig på en ændret tilværelse med en række administrative og repræsentative forpligtelser, men gymnasiasternes personlige problemer blev ved med at interessere ham stærkt.

Han havde en særlig evne til at komme i kontakt med børn og unge mennesker, og begge hans fag, historie og dansk, åbnede gode muligheder for det. Hans menneskelige indstilling fik dem til at føle sig trygge, når de var sammen med ham. I hans hjem kom og gik eleverne, og der blev aldrig skelet til, om de kom fra danske eller tyske hjem.

Eleverne kom til ham med deres sorger og glæder, ofte med en større tillidsfuldhed, end de gik til deres forældre, og han hjalp dem, når de var $\mathrm{i}$ vanskeligheder, og havde altid tid til at høre på dem, hvis de havde brug for det. ${ }^{44}$

Men tag ikke fejl af ham! Han leflede aldrig for eleverne. Han var ikke elevkammerat. Han var deres voksne rådgiver, og selv om han mere følte sig som ungdomsvejleder end som højtstående skoleembedsmand, blev forholdet mellem ham og eleverne aldrig et forhold mellem to ligestillede parter. Han var $\mathrm{i}$ kraft af sin alder og sin stilling den erfarne, og han prøvede at påvirke eleverne og vise dem vejen frem, men ville de ikke tage ved lære af ham, var forholdet ganske vist stadig det samme, men de fik hans kritik at høre.

Sådan var også det budskab, han et år - i 1949 - lagde frem i sin dimissionstale: "Hvis jeg skal vurdere dette års dimittender, så vil jeg sige, at der næppe er mange af jer, der kommer til at dyrke videnskaben, ja, der er næppe mange af jer, der kommer til at gennemgå en akademisk uddannelse. Jeg holder meget af jer, og derfor er det bedst, at I af mig hører nogle sandheder, som I måske synes er ubehagelige. Jeg synes, at nogle af jer for meget har haft tilbøjelighed til at føle jer forurettede. Jeg tror, at adskillige af jer har overvurderet jer selv og jeres evner. I har troet, at I let kunne klare enhver situation uden alt for meget slid og al for megen opmærksomhed. Men uden flid og uden koncentration kommer man ingen vegne. Det gør ikke noget, at 
man ikke når de store resultater, hvis man har gjort sin pligt, men det er altid lidt kedeligt, hvis man ved flid kunne have nået adskilligt højere. Nogle af jer har været mere ivrige til at stille krav end til selv at yde. Måske har eksamen bidraget til at korrigere jeres meninger om disse ting, og hvis der er mere tilbage, vil livet hurtigt belære jer om, at flid skal der til alle steder og koncentration om arbejdet, og jo før I forstår det og indretter jer efter det, jo bedre er det for jer selv $\ldots \ll 45$

Jo, kritikken kunne af og til være hård, men der bankede et varmt hjerte bag ordene.

\section{Hvorfor?}

Hverken inden for folkeskolen eller gymnasieskolen mærkede man de første måneder så meget til den tyske besættelse, men i begyndelsen af 1941 begyndte den at sætte sig sine spor, bl.a. i form af krav om betydelige besparelser. For Haderslev Katedralskoles vedkommende betød det bl.a., at en række vedligeholdelsesarbejder blev standset, og at lønnet tilsyn med skolens undervisningsmaterialer blev stoppet. Værre var det, at det et par uger senere p.g.a. rationering blev nødvendigt at skære kraftigt $\mathrm{i}$ skolens brændselstilførsler. Egeberg så da ingen anden udvej end at forkorte undervisningstiden. Der blev indført lektioner på kun $\mathbf{4 0}$ minutter, alle frikvarterer, undtagen spisefrikvarteret, blev skåret ned til 5 eller 10 minutter, og skolen begyndte forst lidt i ni og sluttede allerede lidt $i$ to. ${ }^{46}$

I pinsen 1941 rygtedes det pludseligt $i$ byen, at Egeberg ønskede at forlade Katedralskolen, og at han havde søgt den ledige stilling som rektor for Sønderborg Statsskole. Ingen vidste rigtig, hvor rygtet stammede fra, men sindene kom øjeblikkeligt i kog: Det kunne da umulig være rigtigt. Han var jo næsten lige kommet. Havde de ikke taget godt imod ham, og havde de ikke på alle måder vist ham, hvor glade de var for ham? Og så ville han vende dem ryggen? Umuligt!

Aldrig så snart var Egeberg vendt hjem 2. pinsedag, før en repræsentant for lærerkollegiet henvendte sig i rektorboligen og bad om en samtale. Egeberg beklagede dybt, at sagen var sivet ud på et tidspunkt, hvor han var bortrejst, men, jo, rygtet talte til dels sandt, mere kunne han ikke sige. ${ }^{47}$

Alle var målløse, og mange fældede øjeblikkeligt en hård dom over ham. De kendte imidlertid ikke sagens rette sammenhæng og var slet 
ikke klar over, hvilket både ydre og indre pres Egeberg havde været udsat for.

I dag kender vi baggrunden - den fremgår af sagens akter: Straks da det ledige rektorat ved Sønderborg Statsskole blev opslået i begyndelsen af maj, havde undervisningsinspektoren for gymnasieskolerne henvendt sig til Egeberg og havde opfordret ham til at søge stillingen. Undervisningsinspektøren begrundede sin opfordring med, at Egeberg på så udmærket vis havde forstået at overvinde de mange nationale vanskeligheder i Haderslev i de fire år, han indtil nu havde været rektor dér, og at der netop i Sønderborg, på den udsatte post tæt ved grænsen, var brug for en mand som ham.

Efter nogle dages grundig overvejelse, svarede Egeberg nej tak til opfordringen. Han befandt sig godt i Haderslev og var blevet så fint modtaget, og han var sikker på, at det blandt lærere, elever og forældre ville blive betragtet som utaknemmeligt af ham, hvis han så hurtigt brød op.

Efter ansøgningsfristens udløb henvendte undervisningsinspektøren sig imidlertid atter til Egeberg. Han måtte sige ja. Der var nationale spændinger på Sønderborg Statsskole, og det var meget vigtigt, at han tog derned. Der var ubetinget brug for ham i Sønderborg! Besættelsen af rektoratet i Haderslev ville ikke tilnærmelsesvis volde ministeriet lige så store vanskeligheder som rektoratet i Sønderborg, meddelte undervisningsinspektøren.

Det pres kunne Egeberg ikke modstå. Han ville meget nødig forflyttes, men ville på den anden side også meget nødig være afvisende over for sine foresatte i ministeriet. Efter at have overvejet sagen endnu et par dage, indtog han det standpunkt, at det til syvende og sidst måtte være hans pligt at gøre tjeneste dér, hvor man på højere sted mente, han kunne gøre bedst fyldest. Ligefrem søge stillingen i Sønderborg ville han under ingen omstændigheder, men 24 . maj meddelte han kortfattet ministeriet, at han stillede sig til disposition, hvis man skulle finde det formålstjenligt at forflytte ham. Det lod ministeriet sig ikke sige to gange. Sidst $\mathrm{i}$ juni blev han udnævnt til rektor for Sønderborg Statsskole pr. 1. august $1941 .^{48}$

\section{Sønderborg}

De nationale spændinger i Sønderborg var i begyndelsen af 1940'erne alvorligere end de fleste andre steder i Sønderjylland, og tonen var 
skarpere. Ulykkeligvis lykkedes det ikke for Sønderborg Statsskole at holde de nationale modsætninger uden for skolen. Det skyldtes bl.a., at en af lærerne både $\mathrm{i}$ foredrag og $\mathrm{i}$ artikler $\mathrm{i}$ aviserne ivrigt agiterede for en konfrontationskurs over for tyskerne. Det var med til at skabe modsætninger, ikke kun i lærerkollegiet, men også blandt eleverne, som flittigt diskuterede lærerens virksomhed. Da læreren angiveligt også benyttede sine historietimer til politisk agitation, klagede en af eleverne over undervisningen. Sagen nåede ministeriet, som forsøgte at få den ordnet $\mathrm{i}$ mindelighed. Det var imidlertid ikke muligt. Både Justitsministeriet og Udenrigsministeriet var, p.g.a. klager bl.a. fra politimesteren i Sønderborg, også indblandet, og Undervisningsministeriet blev tilsyneladende trods støtte til læreren fra bl.a. rektor West og fra en del af befolkningen i Sønderborg presset til i juni 1941 at fritage læreren for tjeneste og senere forflytte ham til Roskilde Katedralskole. - Læreren rejste, men det gjorde nu ikke de nationale spændinger på skolen og i byen mindre. Måske nærmere: Tværtimod! ${ }^{49}$

Det var Egebergs evner som national brobygger, der havde fået ministeriet til at sætte så meget ind på at få ham til Sønderborg, og her ventede der ham en betydelig opgave af national-folkelig karakter.

Egebergs indsats for det nationale skal ses i lyset af hans ønske om at eliminere modsætningsforholdet mellem dansk og tysk i grænselandet. For Egeberg var nationalfølelse ikke noget med store folkefester og blafrende flag. Det var noget med tolerance, både nationalt, politisk og socialt, og noget med at gøre en indsats for at forstå hinanden på tværs af alle grænser. Han benyttede ofte sine taler og foredrag til at slå fast, at danskhed ikke er foreneligt med had til et andet folk eller til et politisk system. Egeberg mente, at det på det nationale område gjaldt om at virke mere ved sit væesen end ved sine ord. For ham var nationalfølelse intet værd, hvis den ikke blev praktiseret $i$ hverdagen..$^{50}$

Det forklarer den store omsorg, som Egeberg altid viste sine tyske elever. Han tvang dem aldrig til at deltage i noget, der måtte være dem imod af nationale grunde, og han gjorde aldrig forskel på eleverne. Danske og tyske elever blev altid behandlet ens, og legater og flidsbelønninger uddeltes som en selvfølge efter behov og uden hensyn til nationalt sindelag. Han gjorde det ikke kun, fordi det politisk set var det klogeste, men fordi det var den eneste menneskeværdige kurs. "Skolen skal ikke prædike nationalhad. Vi har ikke lagt vor un- 
dervisning om for at tækkes tyskerne, men når de tyske elever er loyale og viser os tillid, gengælder vi den. Man kan ikke straffe børn for, hvad deres forældre har gjort «, ${ }^{51}$ udtalte han i 1949.

Som rektor fik Egeberg altid ansøgningerne tilsendt, når en lærerstilling ved hans skole skulle nybesættes, og han havde ret til at indstille til ministeriet, hvilken af ansøgerne, han helst ville have udnævnt. Fra disse indstillinger ved vi, hvad Egeberg ud over de faglige kvalifikationer lagde vægt på, når der skulle ansættes nye lærere. Han ville for alt $i$ verden undgå lærere, der ved deres optræden virkede nationalt ophidsende. Han foretrak lærere, der var udjævnende og forsonende, og som aldrig kunne finde på at såre børn fra tyske eller nazistiske hjem. ${ }^{52}$

I 1945 lukkede det tyske gymnasium og en del tysksindede børn og unge blev overført til Sønderborg Statsskole. Det blev en barsk omvæltning for disse nye elever. En af dem, direktør Ejnar Møller, har mange år senere fortalt, hvorledes de desillusionerede og temmelig forvirrede og usikre begyndte på Sønderborg Statsskole: "I denne situation var det især én mand, der gjorde et stærkt indtryk på mig, nemlig rektor Egeberg Jensen. Hans livssyn var præget af tolerance og kærlighed til sine medmennesker, og det var så dybt forankret i hans personlighed, at han ganske naturligt handlede derefter uden at lade sig påvirke af den herskende opinion og uden at gå på akkord med sin nationale og politiske overbevisning ${ }^{5.53}$

\section{Kristentroen}

Egeberg omtalte ofte den danske skole som en datter af den kristne kirke. For ham betød det, at børnene skulle opdrages i den kristne tro. Kristentroen var grundpillen i hele Egebergs tilværelse. En gang imellem beklagede han sig ganske vist over trosvanskeligheder, ${ }^{54}$ men han var aldrig i tvivl om, hvorpå han byggede sit liv. Han udtrykte flere steder ${ }^{55}$ tak til sine forældre, fordi han i sit barndomshjem modtog en stærk religiøs påvirkning. I Egebergs hjem var man grundtvigianere, og han forblev livet igennem tro mod Grundtvigs anskuelser og den deraf opståede åndsretning.

For Egeberg var det magtpåliggende at viderebringe det kristne budskab og at påvirke andre, så de kunne forstå, at den eneste vej til frelse går igennem troen på Jesus Kristus. I langt den overvejende del af Egebergs skoletaler kom han på et eller andet tidspunkt ind på 
Rektor Egeberg Jensen fotograferet $i$ forbindelse med pensioneringen $i$ 1958. Foto i privateje.

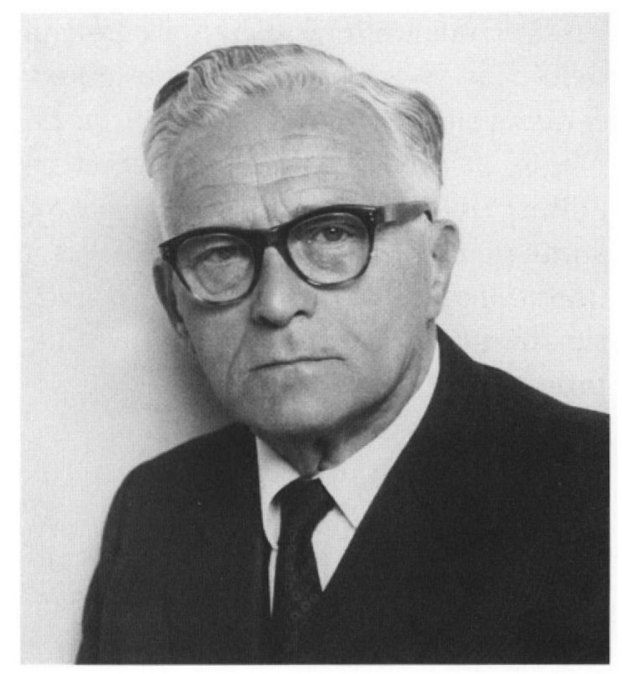

kristendommen og dens betydning for mennesker, ja, nogle af skoletalerne er ganske enkelt udformet som én lang prædiken. Dette gælder ikke mindst juletalerne, men også nogle af dimissionstalerne er domineret af det kristne budskab og dets betydning for mennesker. Netop fordi kristendommen var centrum i Egebergs egen tænkning, kom kristentroen til at præge hans taler, uanset hvad emnet og anledningen så ellers var. ${ }^{56} \mathrm{Da}$ Egeberg i sommeren 1958 for sidste gang stod på talerstolen på Sønderborg Statsskole og dimitterede årets studenter, sluttede han da også således: "Jeg tror, jeg har mange venner her blandt elever og forældre, og jeg vil da gerne sige til dem, måske for sidste gang, at hvis I synes, at kun naive og tåbelige mennesker kan tro på kristendommens ideer, så står jeg blandt de naive og tåbelige mennesker, der mener, at vi er bundne til vore medmennesker «. ${ }^{57}$

\section{Pensionering}

Egeberg kom til at virke frem til 1958. I skolens festsal tog han om formiddagen den 30 . september 1958 en bevæget afsked med eleverne, og her afsløredes et maleri af ham. Midlerne var fremskaffet ved en indsamling blandt lærere og elever og var en gave til skolen. Om aftenen samledes 450 mennesker i Teaterhotellets store sal for at hylde ham, og her fik han overrakt $5000 \mathrm{kr}$. til en rejse og $8000 \mathrm{kr}$. til en fond, der skulle bære hans navn. 
Græd han, eller lod han sig pensionere med et: Gudskelov? Begge dele! Han indrømmede, at han ikke var i stand til at tage afsked med skolens elever uden at fælde tårer. På den anden side kunne han ikke nægte, at arbejdet, især i eksamensperioderne og ved de store optagelsesprøver, igennem nogle år næsten havde oversteget hans kræfter. Den øgede tilgang til gymnasiet havde $\mathrm{i}$ et par år nødvendiggiort en udvidelse af skolen, men han havde ikke haft kræfter til at påtage sig det store ekstra-arbejde, der ville følge med. Han måtte overlade projektet til sin efterfølger. ${ }^{58}$

Som højtstående skolemand på retræte undgik han naturligvis ikke spørgsmålet: "Hvad synes $\mathrm{De}$ om skoleungdommen nu til dags?« Egeberg beklagede meget, at ungdommen læste mindre end i gamle dage, og at det var svært at skabe interesse for guldalderlitteraturen blandt de unge. Men han måtte indrømme, at han holdt så utrolig meget af at færdes blandt børn og unge, at han ind imellem kunne have lidt svært ved at se deres fejl. "Men som noget generelt må det nok siges, at børn og unge nu om stunder er langt mere adspredte og i nogen grad mangler koncentrationsevne“, udtalte han, og man kan næsten ikke lade være med at trække på smilebåndet, når han fortsætter: "Mon ikke radioen må tage noget af skylden? $\ll^{59}$

\section{Afslutningen}

Egeberg var som pensionist nødt til at skrue ned for blusset, men der var stadig bud efter ham, og han fortsatte sin foredragsvirksomhed, så langt som kræfterne rakte.

Selv om arbejdspresset aftog, blev Egebergs helbred dog ved med at volde ham vanskeligheder, og $\mathrm{i}$ begyndelsen af 1961 mente hans læge, at et ophold på Mallorca ville være den bedst mulige kur. Egeberg håbede at kunne komme til kræfter under det mildere klima, og de breve, han skrev hjem, tydede på, at han befandt sig godt og nød opholdet. $^{60}$

Den 25. marts døde han imidlertid pludselig, ramt af en hjertelammelse. De store dagblade bragte straks meddelelsen, og ikke mindst de sønderjyske aviser skrev fyldige nekrologer om Egeberg og alle de spor, som hans mangeårige arbejdsindsats havde sat $i$ landsdelen. Nekrologen i Dannevirke den 27. marts 1961 slutter med følgende sammenfattende karakteristik af personen Egeberg: "Han var et fint 
menneske, præget af hjertelighed og åbenhed og med sans for den fine humor, der forhindrer os $i$ at tage os selv alt for højtideligt «.

Begravelseshøjtideligheden fandt sted i Christianskirken i Sønderborg den 5. april 1961, og Egeberg ligger begravet på Sønderborg Østre Kirkegård.

\section{FORKORTELSER}

$\begin{array}{ll}\text { Dept } & \text { Departement } \\ \text { Jo } & \text { Journalsag } \\ \text { Kt } & \text { Kontor } \\ \text { LAA } & \text { Landsarkivet i Aabenraa } \\ \text { Pk } & \text { Pakke } \\ \text { RA } & \text { Rigsarkivet i Kobenhavn } \\ \text { Sst } & \text { Sammesteds } \\ \text { Underv.min } & \text { Undervisningsministeriet }\end{array}$

Ej A. Egeberg Jensens privatarkiv. Lokalhistorisk Arkiv for Tønder Kommune.

Es A. Egeberg Jensen: "Eksamensskolevæsenet«, i "Kulturelle forhold i Sønderiylland 1920-1942 «. Udgivet af Dagbladet Dannevirke og Sprogforeningen. Haderslev 1943.

FJ Franz v. Jessen: "Håndbog $\mathbf{i}$ det slesvigske Spørgsmåls Historie 1900-1937. I-III «. 1938.

Gl Privatarkiv nr. 5457 Alfred R. Glahn. A.I.3. Pk. 2. RA.

Ha Haderslev-Samfundets Årsskrift. Haderslev.

Hk Haderslev Katedralskole 1920-1945. Udsendt $i$ anledning af 25 års dagen for genoptagelse af dansk undervisning. 7. september 1945.

Sm Sønderjysk Månedsskrift.

Sn A. Egeberg Jensen: Selvbiografiske notitser. Ordenskapitlet. Amalienborg.

Ss Senderborg Statsskole 1920-1970. Udgivet af Sonderborg Samfundet 1970.

Så Sønderjyske Årbøger.

Tj Tønder Statsskoles Jubilæumsbog.

\section{NOTER}

1. Skoleembedseksamen 1903-1924. Københavns Universitet. Humanistisk fakultet. 35.10.07. RA.

2. Jydske Tidende 27/9-1958.
3. Som note 1.

4. Underv.min 2. dept 1. kt Jo 271/1920. RA.

5. A.J. West: "Den højere skole« i FJ bd. III s. 154. Udgivet af Grænseforeningen 1938.

6. A. Egeberg Jensen: "Lektor Rosenkjær«. En nekrolog. Tj 1945 s. $73 \mathrm{ff}+$ "Tre generationer om skolen «. Et interview. Tj 1995 s. 70.

7. Underv.min 2. dept 1. kt Jo 271/1920. RA.

8. Brev af $22 / 12-1920$. Gl.

9. Brev af 7/9-1920. Gl.

10. A. Egeberg Jensen: "Erindringer fra Tønder Statsskole 1920-1930 « i Tj 1935 s. 10.

11. Brev af 22/12-1920. Gl.

12. Brev af 21/10-1922. Gl.

13. Margrete Schultz: "Erindringer fra Tonder 1904-1923« i Så 1987 s. 157.

14. Tender Statsskoles Årsskrift $1921 \mathrm{~s}$. 30.

15. A. Egeberg Jensen: „En kærlighedserklæring til Vestslesvig " i Tj 1945 s. 85.

16. Es s. 56 .

17. Om sangen og dens komponist se Kaj Sorensen: "Om Ernst A. Kiørboe. Komponist til den vestslesvigske hjemstavnssang For en fremmed barskt og fattigt «. Så 1998 s. 105-132.

18. Tønder Statsskoles Årsskrifter 19211937.

19. Brev af 30/11-1920. Gl.

20. Sst + Ej pk 13. Foredrag om litteratur m.m. 1921-59.

21. Om Egebergs foredrag se i øvrigt Hågen Kiil: »Rektor A. Egeberg Jensens foredragsmanuskripter". Sm 1990 s. 292-299.

22. Sn s. 1.

23. Breve af 4/9-1928 og 23/2-1929. Gl.

24. Brev af 22/1-1923. Gl. 
25. Sandsynligvis R.P. Rossen og Andreas Andresen.

26. Boy Høyer, Øster Lindet. Ejer af gården Trøjborg i Bredebro 1906-27.

27. Brev af 3/1-1927. Gl.

28. Poul Andersen: »Mine 9 år i Højer« i Så 1978 s. 152.

29. Sst.

30. Sst.

31. Ej pk 12. Dimissionstale Sønderborg Statsskole 1946.

32. Hågen Kiil: »Rektor A. Egeberg Jensens foredragsmanuskripter«. Sm 1990 s. 294.

33. Underv.min 2. dept 1. kt Jo 319/1925. RA.

34. Brev af 29/4-1918 til missionær $\mathrm{H}$. P. Kampp. Privatarkiv 6773. J litra K nr. 73. A. I. 2. pk 24. RA.

35. Underv.min 2. dept 1. kt Jo 319/1925. RA.

36. Underv.min 2. dept 1. kt Jo 379/1930. RA.

37. Underv.min 2. dept 1. kt Jo 408/1930. RA.

38. Underv.min 2. dept 1. kt Jo 457/1932. RA.

39. Sst.

40. Underv.min 2. dept 1. kt Jo 459/1937. RA.

41. Jydske Tidende 27/9-1958.

42. Ha 1941 s. 51.

43. Ej pk 11. Skoletaler Haderslev 193941.

44. Ha 1961-62 s. 30f. + Poul Andersen: »Mine 9 år i Højer« i Så 1978 s. 150.

45. Ej pk 12. Skoletaler Sønderborg 19411958.
46. Rektors korrespondance D1 19391967. Skrivelser af 8/1-1941 og 27/11941. Haderslev Katedralskoles Arkiv. LAA.

47. Jydske Tidende 27/9-1958 + Dannevirke 21/6-1941 + Ha 1941 s. 51 + Ha 1961-62 s. $30-33$.

48. Underv.min 2. dept 1. kt Jo 280/1941. RA + Rektors journal over afgåede skrivelser 1941-1950. Skrivelse af 23/ 8-1941. Sønderborg Statsskoles arkiv. LAA.

49. Underv.min 2. dept 1. kt Jo 285/1941. $\mathrm{RA}+$ Ss s. $48 \mathrm{ff}$.

50. Ha 1941 s. $44+$ Ej pk. 6. Avisomtale 1949-1958. Udkast til artikel i Jydske Tidende 27/9-1958.

51. Sonderjyden $13 / 7-1949+$ Jydske Tidende 27/9-1958 + Ss s. 58 .

52. Rektors journal over afgåede skrivelser 1941-1950. Sønderborg Statsskoles arkiv. LAA.

53. Ss s. 58.

54. Se fx Ej pk 5. Korrespondance 193561. Brev af 24/1-1961.

55. Se bl.a. Sn s. 1 .

56. Ej pk 11. Skoletaler 1939-41 Haderslev + pk 12. Skoletaler 1941-58 Sønderborg + Hågen Kiil: "Rektor A. Egeberg Jensens foredragsmanuskripter «. Sm 1990 s. 299.

57. Ej pk 12. Skoletaler 1941-58 Sønderborg.

58. Ss s. $73+76$.

59. Ej pk 6. Avisomtale 1949-1958. Udkast til artikel i Jydske Tidende 27/9-1958.

60. Ha 1961-62 s. 30. 